臨 床

ショック，DIC，壊死性筋膜炎を伴う Vibrio vulnificus

敗血症の一救命例

佐賀医科大学付属病院検査部

伊東 秀夫加悦文わ子佐伯 裕二 田中 真一

永沢 善三 南雲 文夫 植田 寛 只野寿太郎

（昭和 60 年 12 月 5 日受付）

(昭和61年 2 月 19 日受理)

Key words: Saved case, Vibrio vulnificus sepsis

要旨

ショック, DIC, 壊死性筋膜炎を伴ったVibrio vulnificus 敗血症の救命に成功した. 患者は54歳の男 性, 農業。昭和 49 年に肝機能障害を指摘されて扔り, 大酒家である。昭和 59 年 8 月 15 日, 左下腿の高度 の疼痛と腫脹が出現し, 近医に入院したが，8月17日にショック状態となったため, 当院に緊急搬送さ れた. septic shock を疑い施行した血液培養でVibrio vulnificus が検出され, 後に DIC も併発した. 左 下腿皮痛病変に対して necrotomy を行い, その所見から壊死性筋膜炎と診断した. 昭和59年11月 8 日, 軽快退院.

Vibrio vulnificus は主として肝機能障害者に, 皮膚病変を伴う経過の早い敗血症を起すことで注目を 集めている，本邦に打いては，1985年 4 月までに，本症例を含めて16例の報告があるが，ショックまた は DICを併発した重症例は，汪とんどが死亡している。本症例は救命しえた点でも貴重な症例と思われ るので，既報の報告例に若干の考察を加えて報告する。

\section{I.はじめに}

Vibrio vuilnificus (以下, V. vulnificus と略) は1976年 Hollis ${ }^{1}$ により Lactate positive vibrio と して最初に報告され，1979年 Farmer ${ }^{2)}$ により $V$. vulnificus と命名された. Blake ${ }^{3)} ら は V$. vulnifius 感染症を感染経路から, 経口感染群と外傷感染群 の 2 群に分類している. 経口感染群は, 新鮮な魚 貝類摂取後 24 時間以内に発症し, 敗血症や皮膚病 変を伴うことが多い重症型で，75\%は基礎疾患と して肝障害, とくに肝硬変をもつといわれる。 こ れに対し外傷感染群は, 受傷創が海水で污染され た後，7日以内に症状が出現するとされるが，敗 血症を伴うことは稀れで, 此較的予後の良い軽症

別刷請求先：(广840-01)佐賀市鍋島町大字鍋島三本杉 佐賀医科大学付属病院検査部

伊東 秀夫
型である。

本邦に拈ける $V$. vulnificus 感染症は，1978年 $\mathrm{Matsuo}^{4)}$ らの報告に始木るが，その後の報告例は まだ少なく，しかも重症例はほとんどが死亡して いる. 我々はショック, DIC, 壊死性筋膜炎を伴っ たV.vulnificus 敗血症を経験し, 救命に成功した ので報告する。

\section{II. 症 例}

患者：54歳，男性. 農業.

主訴：左下腿の疼痛拈よび腫脹。

家族歷: 父が上顎癌, 母と兄が胃癌でいずれも 死亡.

既往歴：昭和 49 年に肝機能障害を指摘される。 輸血歴 (一).

生活歴: 日本酒 $3 \sim 4$ 合/日. 魚貝類を好む.

現病歴：昭和 59 年 8 月 13 日頃から左下腿の痛搔 
Table 1 Laboratory Findings on Admission

\begin{tabular}{|c|c|c|c|}
\hline \multicolumn{2}{|l|}{ Urinalysis } & \multicolumn{2}{|c|}{ Blood chemistry } \\
\hline Protein & $1(+)$ & T.P & $5.7 \mathrm{~g} / \mathrm{dl}$ \\
\hline Occcult b & $3(+)$ & Alb. & $2.8 \mathrm{~g} / \mathrm{dl}$ \\
\hline ESR & $21 \mathrm{~mm} / \mathrm{h}$ & ZTT & $5.1 \mathrm{~K}-\mathrm{U}$ \\
\hline \multicolumn{2}{|c|}{ Hematological studies } & T. Bil & $1.2 \mathrm{mg} / \mathrm{dl}$ \\
\hline $\mathrm{RBC} \quad 3$. & $3.77 \times 10^{6} / \mu 1$ & GOT & $185 \mathrm{I} . \mathrm{U} / l$ \\
\hline $\mathrm{Hb}$ & $13.6 \mathrm{~g} / \mathrm{dl}$ & GPT & $97 \mathrm{I} . \mathrm{U} / l$ \\
\hline Ht & $37.9 \%$ & $\mathrm{LDH}$ & $1173 \mathrm{I} . \mathrm{U} / l$ \\
\hline WBC & $3100 / \mu 1$ & ALP & 117 I.U/l \\
\hline stab. & $87 \%$ & $\gamma \cdot \mathrm{GTP}$ & 183 I.U $/ l$ \\
\hline seg. & $7 \%$ & ChE & $356 \mathrm{I} . \mathrm{U} / l$ \\
\hline lymph. & $6 \%$ & CPK & $6940 \mathrm{I} . \mathrm{U} / l$ \\
\hline Plt. $\quad 2$ & $2.4 \times 10^{4} / \mu 1$ & T. Chol. & $73 \mathrm{mg} / \mathrm{dl}$ \\
\hline \multicolumn{2}{|c|}{ Coagulation studies } & BUN & $35.2 \mathrm{mg} / \mathrm{dl}$ \\
\hline PT & $52 \%$ & Creat. & $3.0 \mathrm{mg} / \mathrm{dl}$ \\
\hline APTT & $103 \%$ & $\mathrm{~K}$ & $3.2 \mathrm{mEq} / l$ \\
\hline Fbg. & $579 \mathrm{mg} / \mathrm{dl}$ & \multicolumn{2}{|c|}{ Serological studies } \\
\hline FDP & $245 \mathrm{ng} / \mathrm{ml}$ & CRP & $>6(+)$ \\
\hline \multicolumn{2}{|c|}{ Bleeding time $>10 \mathrm{~min}}$. & $\mathrm{HBs}-\mathrm{Ag}$ & $(-)$ \\
\hline & & AFP & $2.5 \mathrm{ng} / \mathrm{ml}$ \\
\hline
\end{tabular}

い感じを自覚したが放置. しかし，8月15日の夜 間から急激に左下腿の疼痛・腫脹が高度となり, $38.5^{\circ} \mathrm{C}$ の発熱もみられたため，8月16日近医（整 形外科）に入院. 抗生剂の投与を受けたが，8 月 17日には左下腿の腫脹はさらに増強し, ショック 状態となったため, 当院に緊急搬送された。

入院時現症：血圧 $60 / \sim \mathrm{mmHg}$, 脈拍 $120 /$ 分, 整, 体温 $36.9^{\circ} \mathrm{C}$ 。意識清明で, 心音・呼吸音には 異常なし，腹部で右季肋部に圧痛がみられたが，
筋性防禦はなく，肝脾腫や腹水は認めなかった。 左下腿の腫脹・圧痛が著明で, 左下腿周囲 $38 \mathrm{~cm}$, 右下腿周囲 $33 \mathrm{~cm}$ であったが，皮膚には創はなく， 表在リンパ節も触知しなかった。

入院時検查成績：尿検査で血尿，蛋白尿がみら れ，沈渣では赤血球円柱を認めた。末梢血では， 白血球は $3,100 / \mu 1$ とむしろ減少しているが，核の 左方移動を伴っていた。血小板は $2.4 \times 10^{4} / \mu 1$ と 著明に減少している，血液生化学検查では，低蛋 白血症拉よび総コレステロール，コリンェステ ラーゼの低下がみられ，肝予備能の低下を思わせ た. GOT 優位のトランスアミナーゼの上昇があ り, LDH, CPK が著しい高値を示していた。 また， $\mathrm{BUN}$, クレアチニンの上昇がみられ, CRP は強陽 性であった（Table 1).

入院後経過 (Fig. 1): 入院時, 血圧低下・頻脈・ 乏尿とショック状態であったため, 対症的に処置 するとともに, septic shockを疑い直ちに血液培 養を施行した。左下腿は腫脹が高度であったが, 皮膚には創はなく，淡い発赤を認めるのみで，主 たる病変は皮下から筋層にあることをらかがわせ た。感染源不明のため，当初はブドウ球菌による 蜂窩織炎を疑い, ペニシリン系抗生剂の投与を 行った。しかし，8月20日に血液培養でグラム陰 性桿菌が検出されたため，セフチゾキシム，ゲン タマイシンに変更. 検出菌は 8 月 23 日に V.vulnificus と同定された。

Table 2 Biochemical characteristics

\begin{tabular}{llll}
\hline Growth on MacConkey's & $(+)$ & Nutrient broth without $\mathrm{NaCl}$ & $(-)$ \\
Growth on SS-SB & $(+)$ & Nutrient broth with $0.5 \% \mathrm{NaCl}(+)$ \\
Growth on TCBS & $(+)$ & Nutrient broth with $6.0 \% \mathrm{NaCl}(+)$ \\
Oxidase & $(+)$ & Nutrient broth with $7.0 \% \mathrm{NaCl}(-)$ \\
Gas from glucose & $(-)$ & Acid form & \\
Nitrate reduction & $(+)$ & Adonitol & $(-)$ \\
Citrate (Simmons) & $(-)$ & Arabinose & $(-)$ \\
Urease & $(-)$ & Cellobiose & $(+)$ \\
Indole & $(+)$ & Glucose & $(+)$ \\
VP & $(-)$ & Inositol & $(-)$ \\
ONPG & $(+)$ & Lactose & $(+)$ \\
Arginine & $(-)$ & Maltose & $(+)$ \\
Lysine & $(+)$ & Mannitol & $(+)$ \\
Ornithine & $(+)$ & Sucrose & $(-)$ \\
\hline (-)* $:$ positive after $48 \mathrm{hrs}$. & & &
\end{tabular}


Fig. 1 Clinical Course
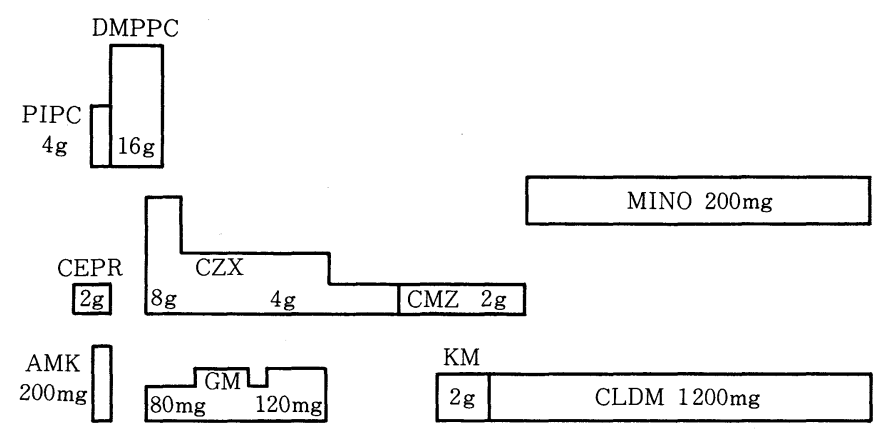

FOY $2 \mathrm{~g}$
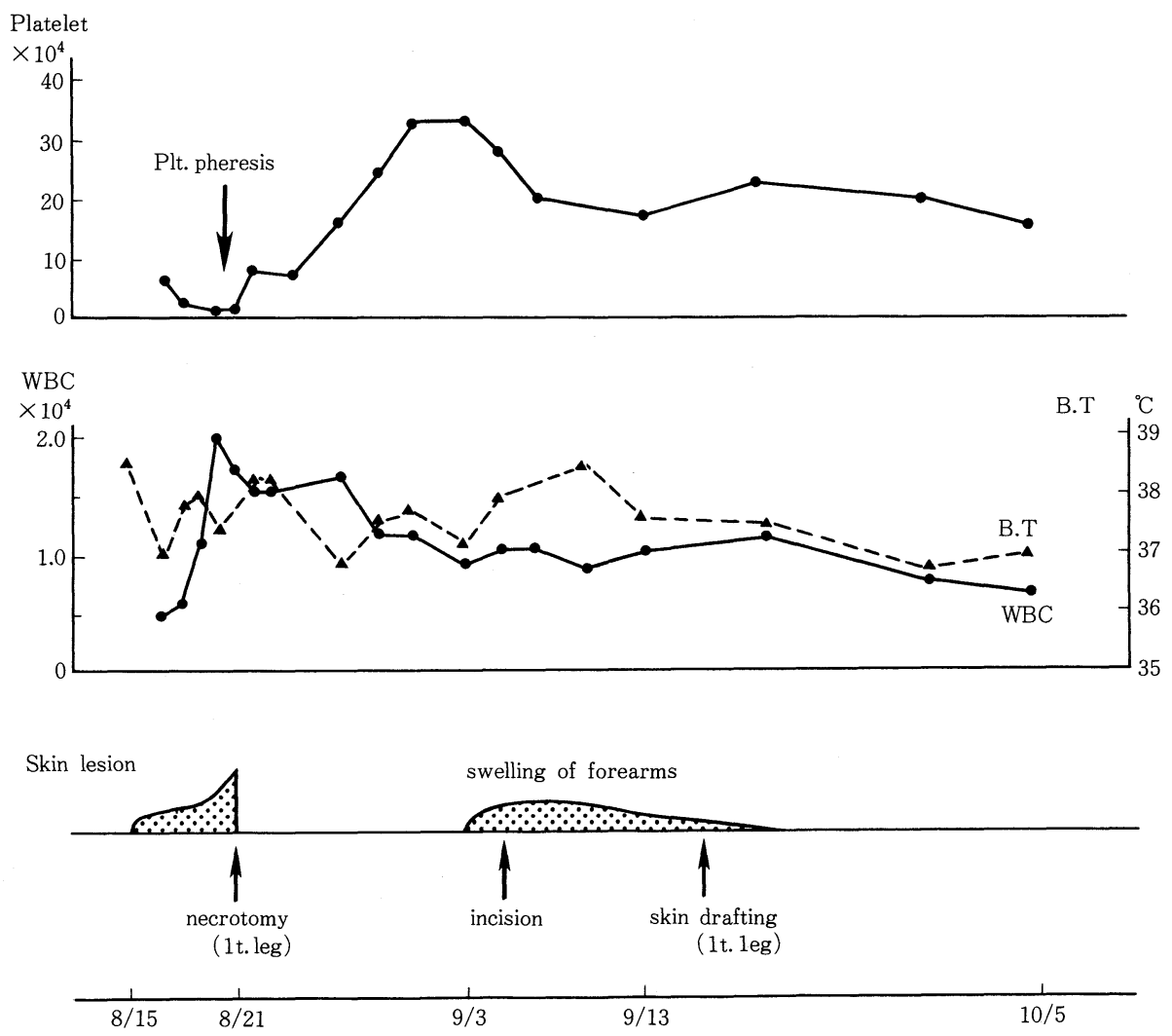

入院時, 血小板は $2.4 \times 10^{4} / \mu 1$ と減少が著しい。 検査成績はDIC と診断できるものではなかった が，Gabexate (FOY) 2g/日の投与を開始した。 しかし，8月21日（入院 5 病日）には血小板は $8,000 / \mu 1$ まで低下し, 検査成績も DIC に典型的 なものとなった。 また，皮膚病変も左下腿から大 腿部へと拡大傾向を示したため, 血小板フェレー
シスを行らとともに, 左下腿の necrotomyを施 行. 皮下脂肪織から筋層にかけて広範な壊死・変 性を認め, 壊死性筋膜炎と診断した. necrotomy 扣よび術前に行った病変皮膚組織の細菌培養で は, 細菌は検出されなかった。

8 月21日以降は順調に経過していたが， 8 月 30 日頃から再び $38.0^{\circ} \mathrm{C}$ 前後の発熱がみられ，9月 3 
日には入院時の皮膚病変と同様の発赤・腫脹が両 前腕に出現した。諸細菌培養は陰性であったが, 减張切開を行い，抗生剂をミノサイクリン，クリ ンダマイシンに变更することにより改善し, 昭和 59年11月 8 日に軽快退院した。

\section{III. 分離菌の細菌学的検査結果}

動脈血培養で分離された菌は，グラム陰性桿菌 で，菌体は彎曲，コンマ状の形態的特徵を有して いた. TCBS 培地では発育良好に緑色の集落形成 を認めた。 血液寒天培地, チョコレート培地では, 灰白色の粘着性を帯びた集落を形成し，BTB 寒 天培地では48時間培養後に小さな集落形成を認め た. 生化学的性状は Oxidase $(+)$, Indole $(+)$,
ONPG (+) で, Citrate (Simmons) は48時間後 に陽性となった. Glucose (十)だが，ガス産生は なく，Lactose（十）である。食塩耐性試験では $0.5 \%$ か $6 \%$ の範囲で菌の発育がみられた (Table 2). 以上の細菌学的特徵より, V. vulnificus と同定

Table 3 Susceptibility (MIC, $\mu \mathrm{g} / \mathrm{ml}$ )

\begin{tabular}{lrlr}
\hline ABPC & 0.78 & LMOX & 0.10 \\
PIPC & $\leqq 0.025$ & CZX & $\leqq 0.025$ \\
MDIPC & $>50$ & CMX & $\leqq 0.025$ \\
CEZ & 6.25 & CPZ & $\leqq 0.025$ \\
CCL & 1.56 & GM & 3.12 \\
CTM & 3.12 & AMK & 12.5 \\
CMZ & 6.25 & MINO & 0.05 \\
CFS & $>50$ & CLDM & 12.5 \\
\hline
\end{tabular}

Table 4 Case reports with infectious disease caused by V. vulnificus in Japan (as of April, 1985)

\begin{tabular}{|c|c|c|c|c|c|c|c|c|c|c|c|c|c|}
\hline case & age & sex & $\begin{array}{c}\text { basic } \\
\text { disease }\end{array}$ & $\begin{array}{l}\text { contact to } \\
\text { seawater }\end{array}$ & wound & $\begin{array}{l}\text { eating } \\
\text { sea food }\end{array}$ & $\begin{array}{l}\text { latent } \\
\text { time }\end{array}$ & diarrhea & $\begin{array}{l}\text { skin } \\
\text { lesion }\end{array}$ & $\begin{array}{l}\text { fever } \\
\left({ }^{\circ} \mathrm{C}\right)\end{array}$ & WBC & DIC shock & $\begin{array}{l}\text { from onset } \\
\text { to death }\end{array}$ \\
\hline $\begin{array}{c}\text { 1. Nagasaki } \\
(1978,10)\end{array}$ & 62 & $\mathrm{M}$ & LC & fishing & $(-)$ & $?$ & $8 \mathrm{hrs}$ & $(+)$ & $(+)$ & 38.2 & 7800 & $(-) \quad(+)$ & 2 days \\
\hline 2. Ōsaka $\begin{array}{c}(1980,7) \\
\end{array}$ & 49 & M & $\begin{array}{c}\text { LC, DM } \\
\text { HCC }\end{array}$ & $(-)$ & $(-)$ & favorite & $?$ & $(-)$ & $(+)$ & 38.8 & 5000 & $(+)(+)$ & 1 day \\
\hline 3. Ōsaka $\begin{array}{c}(1980,9) \\
\end{array}$ & 48 & $\mathrm{M}$ & LC & $?$ & $(-)$ & $?$ & $?$ & $(+)$ & $(++)$ & 39.8 & $?$ & $(+)(-)$ & improve \\
\hline $\begin{array}{c}\text { 4. Ōsaka } \\
(1981,8)\end{array}$ & 72 & M & DM & $?$ & $?$ & shellfish & $?$ & $(+)$ & $(+)$ & 40.0 & $?$ & $(-)$ & 32 days \\
\hline 5. Kumamoto & 63 & $\mathrm{M}$ & LD & $(-)$ & $(-)$ & raw fish & $12 \mathrm{hrs}$ & $?$ & $(+)$ & 38.8 & $?$ & $(+)$ & 3 days \\
\hline 6. Toyama $(1981,12)$ & 75 & F & $\begin{array}{l}\text { C. Cho. } \\
\text { MR }\end{array}$ & $?$ & $?$ & $?$ & $?$ & $(-)$ & $(-)$ & $(-)$ & $?$ & $(-) \quad(-)$ & improve \\
\hline $\begin{array}{l}\text { 7. Fukuoka } \\
(1982,7)\end{array}$ & 59 & M & A. anemia & $?$ & $?$ & cuttlefish & $24 \mathrm{hrs}$ & $(+)$ & $(-)$ & 39.3 & $?$ & $(+)$ & 1 days \\
\hline $\begin{array}{r}\text { 8. Kanagawa } \\
(1982,8)\end{array}$ & 72 & F & LC & $(-)$ & $(-)$ & dried fish & $12 \mathrm{hrs}$ & $(+)$ & $(+)$ & 39.8 & 3000 & $(+)(+)$ & 13 days \\
\hline $\begin{array}{c}\text { 9. Tokyo } \\
(1983,6)\end{array}$ & 47 & M & LC & $(-)$ & $(-)$ & favorite & $?$ & $(+)$ & $(+)$ & 38.6 & 3400 & $(+)(+)$ & 4 days \\
\hline $\begin{array}{l}\text { 10. Tokyo } \\
(1983,9)\end{array}$ & 53 & M & LC & cooking & $(-)$ & favorite & $?$ & $(+)$ & $(+)$ & 38.9 & 13200 & $(-) \quad(-)$ & improve \\
\hline $\begin{array}{c}\text { 11. Nagasaki } \\
(1984,7)\end{array}$ & 61 & $\mathrm{M}$ & LC & $(+)$ & $(+)$ & $(-)$ & 2 days & $?$ & $(+)$ & 39.8 & 9800 & $(+) \quad(+)$ & improve \\
\hline $\begin{array}{l}\text { 12. Fukuoka } \\
(1984,7)\end{array}$ & 62 & $\mathrm{M}$ & $(-)$ & $?$ & $?$ & $?$ & $?$ & $?$ & $(+)$ & 39.6 & 13000 & $(-)(+)$ & improve \\
\hline $\begin{array}{l}\text { 13. Fukuoka } \\
(1984,8)\end{array}$ & 56 & M & LC & $(-)$ & $(-)$ & Sushi & $24 \mathrm{hrs}$ & $(-)$ & $(-)$ & 38.6 & 12600 & $(-) \quad(-)$ & improve \\
\hline $\begin{array}{l}\text { 14. Tokyo } \\
(1984,8)\end{array}$ & 72 & $\mathrm{~F}$ & LD & $(-)$ & $(-)$ & dried fish & $12 \mathrm{hrs}$ & $(+)$ & $(+)$ & 39.8 & 3000 & $(+)(+)$ & 13 days \\
\hline $\begin{array}{l}\text { 15. Fukuoka } \\
(1984,9)\end{array}$ & 55 & $\mathrm{~F}$ & $\begin{array}{c}\mathrm{LC} \\
\text { Colon } \mathrm{Ca} .\end{array}$ & $(-)$ & $(-)$ & Sushi & $24 \mathrm{hrs}$ & $(+)$ & $(-)$ & 38.1 & 11200 & $(-) \quad(-)$ & improve \\
\hline 16. Saga* ${ }_{(1984,8)}$ & 54 & M & LD & $(-)$ & $(-)$ & favorite & $?$ & $(-)$ & $(+)$ & 38.5 & 3800 & $(+)(+)$ & improve \\
\hline
\end{tabular}

Saga* ${ }^{*}$ our case

LC: liver cirrhosis LD : liver dysfunction HCC: hepatocellular carcinoma DM : diabetes mellitus MR: mitral regurgitation A. anemia : aplastic anemia C. Cho.: chronic cholecystitis 
した ${ }^{18) 99}$.

薬剤感受性は，ピペラシリンと第三世代のセ フェム系抗生剂に良好な感受性を示した（Table 3).

\section{IV. 考 察}

本邦に打ける $V$. vulnifius 感染症の報告は, 1985年 4 月までに, 我々が調べた限りに怙いては, 本症例を含めて16例である (Table 4). 発生時期 は 2 例を除き， 7 月から 9 月に集中しており，発 生地はすべて東京以西である。16例中13例が肝疾 患をもち，1例のみが基礎疾患がない，皮膚病変， ショック，DICを伴わないものの予後は良好であ る. 8 例が死亡しているが，死亡例について検討 してみると，

(1) 肝機能障害, とくに肝硬変を代表とする基礎 疾患がある。

(2) ショックまたはDICを併発している.

(3) 皮膚病変を伴っている.

(4) 白血球増加がない.

という4つの類似点を見い出すことができる。こ のなかで, 白血球数は予後を推測する上で興味深 いが，今後さらに多数例についての検討が必要と 思われる。

初期治療にあたっては, 発症前に海水との接触 や魚貝類摄取の病歴がはっきりしない症例が, 本 例を含めて 16 例中 8 例にみられる点には，注意が 必要である. Blake ${ }^{3)} ら は$ 発症24時間以内に抗生物 質が投与されている例は比較的予後良好で，また 外傷感染では創洗浄も予後に重大な影響を及ぼす としている35). V. vulnificus の 3 濃度法による薬 剂感受性は, ペニシリン系, セファロスポリン系 をはじめ, 多くの薬剤に感受性があるとの報告が 多いが(6) 8) $\mathrm{MIC}$ 值でみてみると，ピペラシリンお よび第三世代のセフェム系抗生剂が優れた抗菌力 を示した。

本例では経過中, 初発部位の左下腿とは異なる 前腕部に，再び皮膚病変の発現をみている。諸細 菌培養陰性で，その原因はわからないが，新たな 污染が考兄られないため, 再発の可能性がある。
本例のよらな重症の $V$. vulnificus 感染症の皮膚 病変の再発傾向については, 重症例の大多数が皮 膚病変の改善をみないまま死亡しているので, 今 後の検討課題として残される。

\section{V. まとめ}

V. vulnificus 感染症は, いったん発症すれば経 過が早く，予後不良である。予後には初期治療が 大きく影響すると考えられるが，Vibrio 属感染を 疑わせる病歴がはっきりしない症例も多く存在す ることには，注意が必要である。 V. vulnificus 感 染症は稀れとはいえ，致死率の高い，夏期に拈け る重要な感染症と考学られる。

本症例の要旨は，第29回日本臨床病理九州地方総会で発 表した。

\section{文献}

1) Hollis, D.G., Weaver, R.E., Baker, C.N. \& Thornsberry, C.: Halophilic vibrio species isolated from blood cultures. J. Clin. Microbiol., $3: 425-431,1976$.

2) Farmer, J.J.: Vibrio (Beneckea) vulnificus, the bacterium assosiated with sepsis, septicaemia, and the sea. Lancet, 2: 903, 1979.

3) Blake, P.A., Merson, M.H., Weaver, R.E., Hollis, D.G. \& Heublein, P.C. : Disease caused by a marine vibrio : Clinical characteristics and epidemiology. N. Engl. J. Med., $300:$ 1-5, 1979.

4) Matuo, T., Kohno, S., Ikeda, T., Saruwatari, K. \& Ninomiya, H.: Fulminating lactose-positive vibrio septicemia. Acta Path. Jap., $28: 937$ $-948,1978$.

5) Thorsteinsson, S.B., Minnus, J.N. \& Musher, D. M. : Clinical manifestation of halophilic nonchorea vibrio infection. Lancet $2: 1283-1284$, 1974.

6）岡本佳千, 矢野 隆, 平井茂美, 他：Vibrio vulnificus敗血症の 2 症例。共済医報, $32: 528-534$, 1984.

7) 前田裕弘, 竹中清吾, 北浦敏行, 他：Vibrio vulnificusによる敗血症で死亡した肝癌の一例と その細菌学的性状. 感染症誌, $56: 335-339,1983$.

8）高宮春男, 片桐文子, 前川和彦, 大谷英樹：Vibrio vulnificus 感染症に関する臨床細菌学的検討. 感 染症誌，56：1032-1036, 1983.

9）薮内英子：最近注目されている病原菌一ビブリ オ・バルニィフィカスー. 日本医事新報, 3032 ： 132-133, 1982. 


\title{
A Saved Case of Vibrio Vulnificus with Shock, DIC and Necrotizing Fascitis
}

\author{
Hideo ITO, Miwako KAETSU, Yuji SAEKI, Shinichi TANAKA, Senzo NAGASAWA, \\ Fumio NAGUMO, Hiroshi UEDA \& Jutaro TADANO \\ Department of Laboratory Medicine, Saga Medical School
}

Vibrio vulnificus infection has gained increasing attention because it often causes serious septicemia with skin lesion and has a high mortality rate. That this infection is found in connection with basic disease, especially hepatic disease, is of great interest. Recently, we have experienced a case of vibrio vulnificus sepsis and succeeded in saving it. As of April, 1985, in Japan, 16 vibrio vulnificus caused cases were reported, including ours; the majority of the more cases ended in death.

A 54-year-old male was admitted, on August 16, 1984, to a neighborhood hospital because of swelling and pain in the left leg. Despite treatment, he fell in shock state and was transferred to our hospital on the next day. Liver dysfunction was pointed out for the patient in 1974. Vibrio vulnificus was isolated from blood culture although he had no history of wound infection following exposure to seawater or eating seafood. The final diagnosis we made was septicemia, septic shock, disseminated intravascular coagulation and necrotizing fascitis, caused by vibrio vulnificus. Antibiotics and anticoagulant agents were administered, and necrotomy was done for the skin lesion. The patient was discharged on November 8, 1984 following remission. 